\title{
Using Courseware Instruction to Improve Junior High School Students' Spatial Visualization Skills
}

\author{
Samuel Adaboh ${ }^{\mathrm{a}}$, Robert Akpalua ${ }^{\mathrm{a}}$ Isaac Owusu-Darko and Samuel \\ Stevens Boateng ${ }^{\mathrm{a}}$ \\ aValley View University, GHANA
}

\begin{abstract}
This study basically focused on the use of instruction to assist Junior High School (JHS 1) students at Dodowa Presbyterian Basic School (Ghana), to achieve high spatial visualization skills which will eventually translate into their mathematics achievement. The test instrument used for the data collection was an adapted form of the Middle Grades Mathematics Project (MGMP) spatial visualization test which comprised of 40 items with an internal consistency reliability of 0.81 . The simple random sampling technique was used to assign 50 students to control and experimental groups. Pretest-posttest control group design was employed for the study. A paired-sample t-test and split plot ANOVA were used to analyze the data. The results showed that even though there was some improvement in spatial visualization skills across board (both control and experimental groups), there was a statistically significant improvement in spatial visualization skills among the experimental group. The study also indicated that there were no gender differences in spatial visualization skills both at the pretest and posttest levels.
\end{abstract}

KEYWORDS

spatial visualization skills, spatial ability, guided discovery teaching method, pre-test and post-test.
ARTICLE HISTORY

Received 15 September 2016

Revised 10 November 2016

Accepted 22 February 2017

\section{Introduction}

Mathematics is one of the most important subjects necessary for academic achievement and success in everyday life. According to Sherrod (2009), those nations in the world which have taken the culture of mathematics and science seriously are leading developmentally, whereas those economies, in which this culture has played little or no role, find themselves lagging behind and their very survival threatened.

\section{CORRESPONDENCE S. Adaboh samuel.adaboh@vvu.edu.gh}

(c) 2017 S. Adaboh et al.

Open Access terms of the Creative Commons Attribution 4.0 International License apply. The license permits unrestricted use, distribution, and reproduction in any medium, on the condition that users give exact credit to the original author(s) and the source, provide a link to the Creative Commons license, and indicate if they made any changes. (http://creativecommons.org/licenses/by/4.0/) 
Because of the importance of mathematics, the burden of developing, students' basic mathematical skills has been a crucial one not only for mathematics educators, but also all stakeholders in education across the globe. In transforming the teaching and learning of mathematics and education in general in Ghana, for instance, the Ministry of Education (MoE) in collaboration with the Teacher Education Division (TED) in 2003 carried out a review of the teacher education curriculum and upgraded all Initial Teacher Training Colleges (ITTC's) to Diploma awarding institutions with the aim of improving teachers' content knowledge and pedagogical skills in the various subject areas. In addition, the MoE in collaboration with other international agencies such as the Japan International Cooperation Agency (JICA), United States Agency for International Development (USAID) and the Department for International Development (DFID) have shown enormous commitment by embarking on mathematics and science projects to improve the teaching and learning of mathematics (Education Strategic Plan, 2003-2015).

However, the challenge is that mathematics achievement has been incessantly below expected standards relative to other subjects. Oke and Bello (2014), in an appraisal of performance among member states of West African Examination Council (WAEC), noted a less than promising performance trend since 2006. Ghana has continually maintained success rates of between $25 \%$ and $30 \%$ in mathematics since 2006 (Oke \& Bello, 2014). In addition to the low level of mathematics achievement mentioned above, many students fail to see the everyday application of school mathematics; rather, they perceive it as something abstract and cold (Bansilal, James \& Naidoo, 2010). To overcome this unfortunate trend, approaches ought to be devised to help link mathematics with everyday life in the classroom so as to help mathematics concept-formation and drive away the fear of the subject among learners.

Fortunately, there is sufficient research to show that any attempt to improve spatial visualization ability of students would lead to an increase in their mathematics achievement. Mix and Cheng (2006) put it succinctly by saying that "the relationship between spatial ability and mathematics achievement is so well established that it no longer makes sense to ask whether they are related." (p. 206). Spatial ability is a cognitive ability that is very important to humans for everyday chores and specialized activities. Battista \& Wheatley (1998), defined spatial ability as "the ability to formulate mental images and to manipulate these images in the mind."(p.18). McGee (1979) also defined spatial visualization as "the ability to mentally manipulate, rotate, twist, or invert a pictorially presented stimulus object" (p. 893).

\section{Statement of the Problem}

There is no doubt that the government of Ghana has been making a lot of investments in manpower training and infrastructural development in the educational sector over the years. Unfortunately, there hasn't been any corresponding academic improvement to justify those investments (Gavor, 2015). At the International level, the two times that Ghana participated in the Trends in International Mathematics and Science Study (TIMSS), we performed so poorly that it was an embarrassment to the whole nation (Fredua-Kwateng, 2005; Anamuah-Mensah et al, 2005). In the 2003 TIMSS mathematics test for grade eight students, it was reported that out of the 45 countries that 
participated in the competition, Ghana finished $44^{\text {th }}$. Ghanaian students scored a total of 276 compared to the international average of 466 . At the national level, the Basic Education Certificate Examination (BECE) results showed the same abysmal performance over the years (Anamuah Mensah et al, 2005; FreduaKwateng, 2005; Education Sector Performance Report, 2016).

As a lower middle income nation, which is eager to develop her manpower needs for accelerated growth, there is the need to pay serious attention to interventions that would lead to increase mathematics achievement by our young ones.

\section{Purpose of the Study}

In Ghana, studies conducted by Eshun (2004), and Eshun and Famiyeh (2005), have indicated that mathematics continues to be the most fearsome subject in the school curriculum. Mathematics as a subject taught in school, generates in many pupils and students a feeling of fear, anxiety, uneasiness and insecurity (Eshun \& Famiyeh, 2005). The general perception of mathematics being the most difficult subject in the school curriculum is reflected in students' performance at both the national and international levels in Ghana over the years. For example, the 1996 and 2000 National Criterion Reference Test (CRT) which established that only $1.8 \%$ and $4.4 \%$ of primary six students' nationwide obtained a mastery mark of $55 \%$ respectively, is a clear manifestation of the negative perception that students have in mathematics (MoE, 2002). In addition, the generally poor performance of Ghanaian students with a students' average of 276 in mathematics which was significantly lower than the international average of 467 in the $3^{\text {rd }}$ Trends in International Mathematics and Science Study (TIMSS, 2003), is further evidence of the status of mathematics teaching and learning in the country.

Fortunately, several research studies have shown that when students are taught to physically fold, cut, twist, mentally visualize and rotate objects, they would be on their way to maximizing their creative skills at solving problems not only in mathematics, but also in other science related subjects (Carter, LaRussa, Bodner, 1987; Mix \& Cheng, 2012). This relationship means that any attempt at improving spatial visualization skills of students will directly have a positive impact on their mathematical achievement.

The purpose of this study therefore was twofold. First, it was to find out the extent to which instruction in spatial visualization will improve spatial visualization skills of students of the Presbyterian Junior High School at Dodowa in the Dangme West District of Ghana. Second, the study was to address the question of whether there was any difference in spatial visualization ability between boys and girls in the same Junior High School classroom.

\section{Objective of the Study}

The main objective of the study was to test whether instruction in spatial visualization could positively influence spatial visualization skills among Junior High School students at Dodowa Presbyterian School. More specifically, the study seeks to:

1. Identify the level of spatial visualization skills possessed by students prior to instruction in spatial visualization. 
2. Ascertain the difference between the level of visualization of both genders in Dodowa Presbyterian JHS one,

3. Find the extent to which instruction in spatial visualization affect students' performance in spatial visualization skills.

\section{Research Questions and Hypothesis}

Two research questions were investigated.

1. Could spatial visualization ability of junior high school students be improved through spatial visualization activities?

2. Is there any difference in spatial visualization ability between males and females junior high school students?

The two null-hypotheses were:

a) $\mathrm{Ho}_{\mathbf{1}}$ : There is statistically no significant difference in the mean gain scores of spatial visualization ability of the experimental and control groups

b) $\mathrm{Ho}_{2}$ : There is no statistically significant difference between males and females in their mean gain scores on spatial visualization ability.

\section{Methodology}

The research design for this study was pretest-posttest control group design which is a quasi-experimental design. An intact Junior High School (JHS) form one class of 50 students was used as the sample for this research. The students were equally assigned to both the experimental and control groups using simple random sampling technique and therefore shared similar characteristics. The test instrument used for the data collection was an adapted form of the Middle Grades Mathematics Project (MGMP) spatial visualization test which comprised of 40 items and has an internal consistency reliability of 0.82. The test items were carefully structured to check ambiguities and inconsistencies. The validity of the test instrument was ascertained by two lecturers at mathematics education department of Valley View University.

A pre-test on spatial visualization ability was administered to both groups following which, the experimental group carried out some spatial visualization activities as part of their training over a period of five weeks. The students in the experimental group, were put into groups of four or five and were given interlocking plastic cubes to form different three-dimensional solids. In addition to forming the three-dimensional solids, the students were encouraged to draw the various plan views (such as front view, top view, right-side view and left-side views) of the solids they formed. In the next stage of the training, they were given isometric drawings of three dimensional figures and asked to determine how many cubes will be needed to construct the figures in the isometric drawings. During the third and final stage of the intervention, the students were taken through paper folding activities such as drawing, cutting and formation of 3 -dimensional objects from nets. The students were also required for example, to identify how the net of a cube would look like when it is folded and repositioned. The researcher then guided students, working in groups of four and five to illustrate their answers with explanations. 
While the experimental group was undergoing this training, the control group followed their normal mathematics class by their mathematics teacher within the same five weeks. All other conditions for the two groups remained the same except the treatment that the experimental group received from the researcher. At the end of the five weeks, spatial visualization skills post-test was administered to both groups and the results recorded.

\section{Administration of Research Methodology}

The table below shows the way the teaching of the experimental group was done within the period.

Table 1. Schedule of activities to enhance spatial visualization skills among experimental group

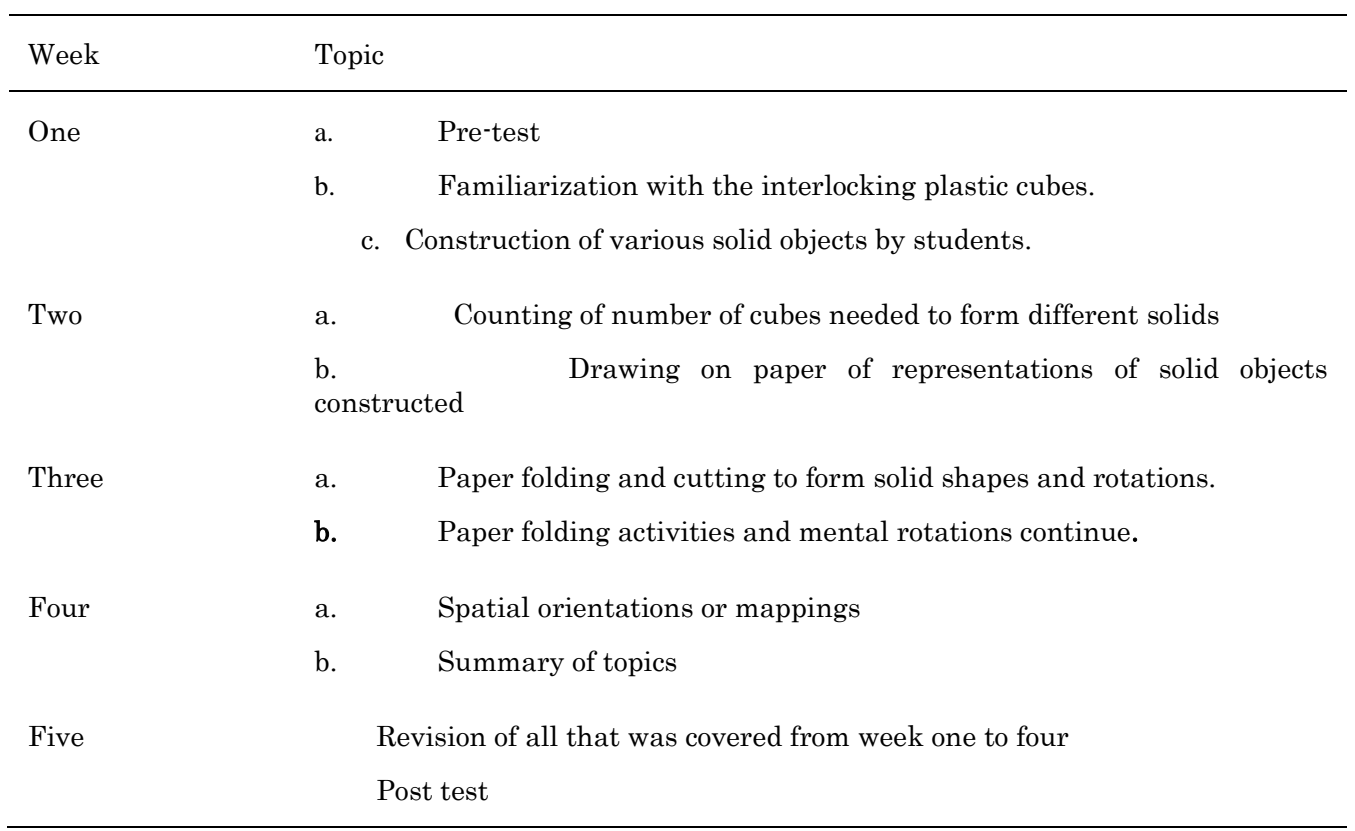

In teaching the students to use the interlocking plastic cubes to construct different solids, the researcher used both direct instruction and the guided discovery approach to enable the students overcome their difficulties in visualization of two and three-dimensional objects. The guided discovery teaching technique serves as one of the most appropriate means of assisting students to learn. By this approach, the goal of teaching spatial visualization skills transcends the borders of students acquiring knowledge of a collection of concepts and skills, but also enables them to think for themselves and become good problem solvers and problem posers (Mereku, 2004). One example of the spatial visualization activities the students were engaged in during the period is shown below.

1. What shape would be obtained when the figure on the left is folded? 


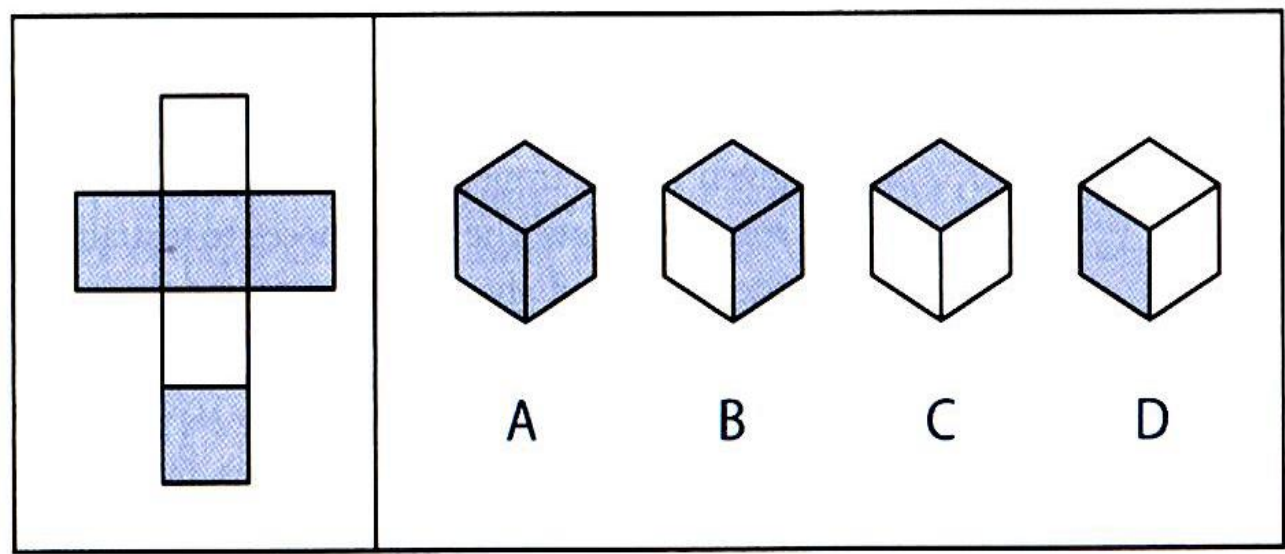

Figure 1. Spatial visualization task involving paper cutting and folding

Students were also guided through group activities to find out without actually counting how many cubes would be needed to build a particular object shown to them, what the back view, front view and top views would look like etc. For the purpose of illustration, one of the tasks that the students performed during the training session is shown below:

2. Without actually counting the cubes, how many cube will be needed to form the following figures? Also draw the front, top and right views of each of the figure below.

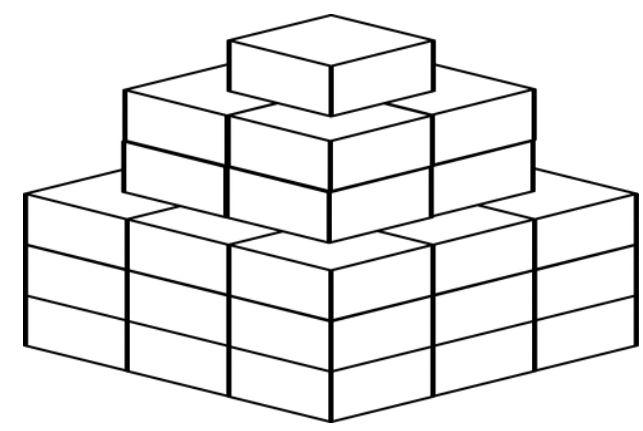

Figure 2. Interlocking plastic cubes to enhance spatial visualization

\section{Results}

The first research question that this study sought to address was "Could spatial visualization ability of Junior High School Students be improved through spatial activities? The accompanying null hypothesis was Ho statistically significant difference in the mean gain scores of spatial visualization ability of experimental and control groups.

To answer the above research question, Table 2 below shows a control group sample statistics output of the mean pretest and posttest scores for 25 students whilst Table 3 shows a similar output for the experimental group. The results of Table 2 show a mean increase of 4.88 in spatial visualization performance of the control group (from a mean pretest score of 10.88 to a mean posttest score of 15.76). 
Table 2. Paired Samples Statistics: Control group output statistics

\begin{tabular}{lllll}
\hline & Mean & N & Std. Deviation & $\begin{array}{l}\text { Std. } \\
\text { Mean }\end{array}$ \\
\hline & Pretest Scores for Control Group 10.88 & 25 & 2.571 & .514 \\
Pair 1 & & & & \\
& Posttest Scores for Control Group15.76 & 25 & 6.679 & 1.336 \\
\hline
\end{tabular}

However, Table 3 which is the experimental group output statistics shows a mean increase in spatial visualization performance of 19.32 (from a mean pretest score of 11.80 to a mean posttest score of 31.20).

Table 3. Paired Samples Statistics: Experimental group output statistics

\begin{tabular}{lllll}
\hline \hline & Mean & N & Std. Deviation & Std. Error Mean \\
\hline & Pretest Scores for Experimental Group 11.80 & 25 & 2.754 & .551 \\
Pair 1 & Posttest Scores for Experimental Group31.20 & 25 & 3.719 & .744 \\
& & & & \\
\hline \hline
\end{tabular}

The above results from tables 1 and 2 show that even though there was an increase from pretest to posttest across board (both control and experimental groups), the increase was much higher in the experimental group than the control group.

Table 3 shows a paired-samples t-test of the experimental group. It could be shown from the table that there was a statistically significant improvement in the students' achievement from the pre-test $(\mathrm{M}=11.80, \mathrm{SD}=2.75)$ to the posttest $(\mathrm{M}=31.20, \mathrm{SD}=3.72)$ and $\mathrm{t}(25)=-19.835, \mathrm{P}<0.0005$. To find the magnitude of the intervention effect, an eta squared was found to be approximately 0.94 . The eta squared statistics (0.94) indicated a large effect size (Cohen, 1988). 
Table 4. Results of Paired Sample T-Test

\begin{tabular}{|c|c|c|c|c|c|c|c|c|}
\hline \multicolumn{9}{|c|}{ Paired Samples Test } \\
\hline & \multirow{3}{*}{ M } & \multicolumn{3}{|c|}{ Paired Differences } & & \multirow[t]{3}{*}{$\mathrm{t}$} & \multirow[t]{3}{*}{$\mathrm{df}$} & \multirow{3}{*}{$\begin{array}{c}\text { Sig } \\
(2 \text {-tailed })\end{array}$} \\
\hline & & $\mathrm{SD}$ & $\begin{array}{l}\text { Std. Error } \\
\text { Mean }\end{array}$ & \multicolumn{2}{|c|}{$\begin{array}{l}95 \% \mathrm{CI} \text { of the } \\
\text { Difference }\end{array}$} & & & \\
\hline & & & & Lower & Upper & & & \\
\hline $\begin{array}{cc} & \text { Pretest Scores } \\
\text { for Experimental } & \text { Group - Posttest } \\
\text { Pair 1 } & \text { Scores for } \\
& \text { Experimental } \\
\text { Group }\end{array}$ & -19.400 & 4.890 & .978 & -21.419 & -17.381 & -19.835 & 24 & .000 \\
\hline
\end{tabular}

The profile plot in Figure 3 also shows the changes that occurred from pretest to posttest for both the experimental and control groups. Students in the control group had their mean performance increased from 10.88 on the pretest to 15.76 on the posttest. The shorter of the two line segments on the graph illustrates the above change. The experimental group which is illustrated by the longer line segment (with the greater slope) also increased from a pretest of 11.80 to a posttest of 31.20 . As a result of this significant change observed in the experimental group compared to the control group, we have a firm basis to conclude that our treatment which is the instruction in spatial visualization had a reliable effect on the students. 


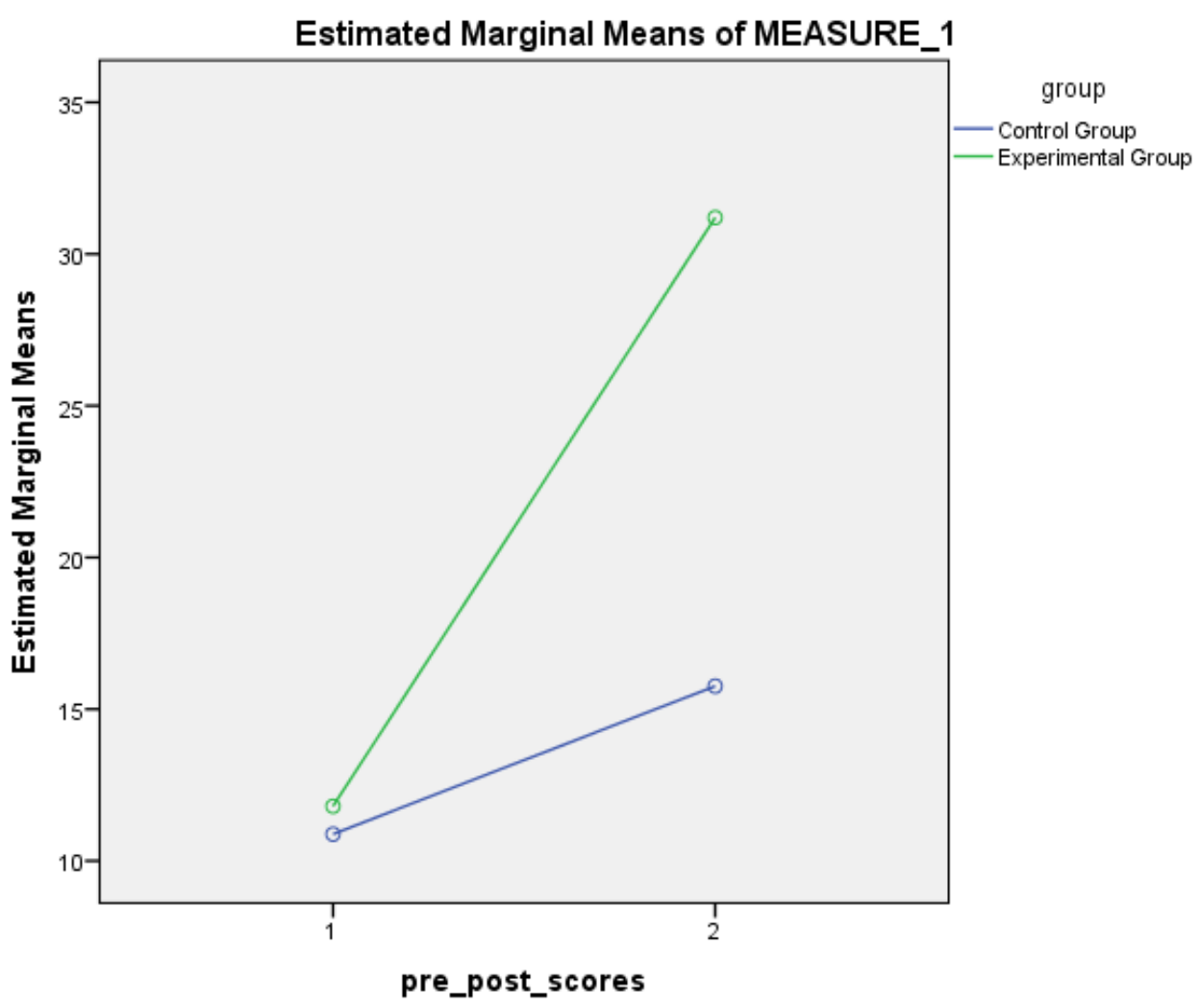

Figure 3. Profile plot of changes that occured from pretest to posttest for both groups

Table 5 is a split plot ANOVA of the pretest- posttest scores by group interaction. An essential part of the split-plot ANOVA is the second row of Table 5. From this table, the pretest_ posttest scores by group interaction showed an F-value of 80.355 with a significant level of almost zero (0.00000000000804). This significant value shows that the pretest-posttest scores by group was highly significant. The result further confirms that there was interaction between the experimental and the control groups. The treatment group increased more than the control group. From the above results, we fail to accept the null hypothesis that there is statistically no significant difference in the mean gain scores of spatial visualization ability of experimental and control groups and conclude that instruction in spatial visualization has significant effect on spatial visualization skills. 
Table 5. Tests of Within-Subjects Effects

Measure: MEASURE_1

\begin{tabular}{|c|c|c|c|c|c|c|c|c|c|}
\hline Source & & $\begin{array}{l}\text { Type III } \\
\text { Sum of } \\
\text { Squares }\end{array}$ & $\mathrm{df}$ & $\begin{array}{l}\text { Mean } \\
\text { Square }\end{array}$ & $\mathrm{F}$ & Sig. & $\begin{array}{l}\text { Partial } \\
\text { Eta } \\
\text { Squared }\end{array}$ & $\begin{array}{l}\text { Noncent. } \\
\text { Parameter }\end{array}$ & $\begin{array}{l}\text { Observ } \\
\text { ed } \\
\text { Power }\end{array}$ \\
\hline \multirow[t]{4}{*}{$\begin{array}{l}\text { Pre_Post_ } \\
\text { Scores }\end{array}$} & $\begin{array}{l}\text { Spherici } \\
\text { ty } \\
\text { Assume } \\
\text { d }\end{array}$ & 3684.490 & 1 & 3684.490 & 224.630 & .000 & .824 & 224.630 & 1.000 \\
\hline & $\begin{array}{l}\text { Greenho } \\
\text { use- } \\
\text { Geisser }\end{array}$ & 3684.490 & 1.000 & 3684.490 & 224.630 & .000 & .824 & 224.630 & 1.000 \\
\hline & $\begin{array}{l}\text { Huynh- } \\
\text { Feldt }\end{array}$ & 3684.490 & 1.000 & 3684.490 & 224.630 & .000 & .824 & 224.630 & 1.000 \\
\hline & $\begin{array}{l}\text { Lower- } \\
\text { bound }\end{array}$ & 3684.490 & 1.000 & 3684.490 & 224.630 & .000 & .824 & 224.630 & 1.000 \\
\hline \multirow[t]{4}{*}{$\begin{array}{l}\text { Pre_Post_ } \\
\text { Scores * } \\
\text { Group }\end{array}$} & $\begin{array}{l}\text { Spherici } \\
\text { ty } \\
\text { Assume } \\
\text { d }\end{array}$ & 1317.690 & 1 & 1317.690 & 80.335 & .000 & .626 & 80.335 & 1.000 \\
\hline & $\begin{array}{l}\text { Greenho } \\
\text { use- } \\
\text { Geisser }\end{array}$ & 1317.690 & 1.000 & 1317.690 & 80.335 & .000 & .626 & 80.335 & 1.000 \\
\hline & $\begin{array}{l}\text { Huynh- } \\
\text { Feldt }\end{array}$ & 1317.690 & 1.000 & 1317.690 & 80.335 & .000 & .626 & 80.335 & 1.000 \\
\hline & $\begin{array}{l}\text { Lower- } \\
\text { bound }\end{array}$ & 1317.690 & 1.000 & 1317.690 & 80.335 & .000 & .626 & 80.335 & 1.000 \\
\hline \multirow[t]{4}{*}{$\begin{array}{l}\text { Error(Pre } \\
\text { _Post_Sco } \\
\text { res) }\end{array}$} & $\begin{array}{l}\text { Spherici } \\
\text { ty } \\
\text { Assume } \\
\text { d }\end{array}$ & 787.320 & 48 & 16.403 & & & & & \\
\hline & $\begin{array}{l}\text { Greenho } \\
\text { use- } \\
\text { Geisser }\end{array}$ & 787.320 & 48.000 & 16.403 & & & & & \\
\hline & $\begin{array}{l}\text { Huynh- } \\
\text { Feldt }\end{array}$ & 787.320 & 48.000 & 16.403 & & & & & \\
\hline & $\begin{array}{l}\text { Lower- } \\
\text { bound }\end{array}$ & 787.320 & 48.000 & 16.403 & & & & & \\
\hline
\end{tabular}

a. Computed using alpha $=.05$ 
To address the second research question: Is there any difference in spatial visualization ability between males and females Junior High School Students? Table 1.6 which provides the summary statistics about the average performance of the students by sex for both pretest and posttest. The 30 girls in all (both control and experimental) who participated in the study had a mean pre-test score of $(\mathrm{M}=11.30, \mathrm{SD}=3.011)$ and a post-test mean score of $(\mathrm{M}=23.43$, $\mathrm{SD}=9.870)$, while the 20 boys had a mean pre-test score of $(\mathrm{M}=11.80, \mathrm{SD}=2.087)$ and a post-test mean score of $(\mathrm{M}=23.55, \mathrm{SD}=9.052)$.

This results show that the boys were just slightly ahead of the girls in both the pretest as well as the posttest scores. Based on the above findings, we fail to reject the null hypothesis which states that there is no statistically significant difference between males and females in their mean gain scores on spatial visualization ability and conclude that there was no significant difference in spatial visualization performance by both sexes.

Table 6. Pretest

\begin{tabular}{lccc}
\hline Gender & $\mathrm{N}$ & Mean & Std. Deviation \\
\hline Female & 30 & 11.03 & 3.011 \\
Male & 20 & 11.80 & 2.067 \\
Total & 50 & 11.34 & 2.677 \\
\hline
\end{tabular}

Table 7. Post test

\begin{tabular}{lccc}
\hline Gender & N & Mean & Std. Deviation \\
\hline Female & 30 & 23.43 & 9.870 \\
Male & 20 & 23.55 & 9.052 \\
Total & 50 & 23.48 & 9.457 \\
\hline
\end{tabular}

\section{Discussion of Findings}

The results of the study have clearly demonstrated that instruction in spatial visualization do impact positively on spatial visualization skills acquired by students. This finding goes to confirm what others such as Mix and Cheng (2012) have already established.

Secondly, if the statement that "investigating spatial visualization is important because of correlational and logical-intuitive support for its relationship to most technical-scientific occupations and especially to the study of mathematics, science, art, and engineering" (Clements, 1983; Linn \& Petersen, 1986) is anything to go by, then it stands to reason that by improving spatial visualization skills of students, it will go a long way to significantly improve mathematics achievement of students in schools.

However, the results of this study does not lend support to the findings of Sorby (2007); Battista, (1990); Ben-Chaim et al. (1988); Tartre, (1990) and others 
that boys perform better in spatial visualization skills than girls. Rather, it goes to confirm the results of Manger and Eikeland (1998), in a study conducted among 724 Norwegian students showed no significant gender difference in spatial visualization.

\section{Conclusions and Recommendations}

At the end of this research, the following conclusions were deducted:

1. Spatial visualization skills of learners could be improved through spatial activities.

2. There is no significant difference in spatial visualization ability between males and females of Junior High School Students in the study context.

It is recommended that to improve students' performance at the Junior High School level in mathematics, emphasis should not only be on improving pedagogy but also on improving spatial visualization skills of the learners. Since this research has shown that there are no sex-related differences in spatial visualization skills, any effort to improve learners' visualization skills should be directed at both sexes equally.

It is also recommended that this intervention should start very early in the education of pupils if we want to generate interest in the young ones in mathematics and engineering subjects in the future.

\section{Disclosure statement}

No potential conflict of interest was reported by the authors.

\section{Notes on contributors}

Samuel Adaboh - Valley View University, Ghana

Robert Akpalu - Valley View University, Ghana

Isaac Owusu-Darko - Valley View University, Ghana

Samuel Stevens Boateng - Valley View University, Ghana

\section{References}

Bansilal, S., James, A., \& Naidoo, M (2010), Whose voice matters? Learners. South African Journal of education, (30), 153-165.

Battista, M. T. (1990). Spatial visualization and gender differences in high school geometry. Journal for Research in Mathematics Education, 21, 47-60.

Battista, M. T., Clements, D. H., Sarama, J., \& Swaminathan, S. (1997). Development of students' spatial thinking in a unit on geometric motions and area. University of Chicago Press.

Battista, M. T., \& Clements, D. H. (1998). Students' spatial structuring of 2D arrays of squares. JRME Online, 29(5), 503-532.

Battista, M.T. \& Wheatley, G. H. (1989). Spatial visualization, formal reasoning, and geometricsolving strategies of pre-service elementary teachers. Focus on Learning Problems in Mathematics 11(4):17-30.

Ben-Chaim, D., Lappan, G., \& Houang, R.T. (1988). The effects of instruction on spatial visualisation skills of middle school boys and girls. American Educational Research Journal, 25 (1), 51-71.

Bruner, J. (1966). Toward a theory of instruction. Cambridge, MA: Harvard University Press. 
Carter, C. S., LaRussa, M. A., \& Bodner, G. M. (1987). A study of two measures of spatial ability as predictors of success in different levels of general chemistry. Journal of Research in Science Teaching, 24, 645-657.

Clements, M. A. (1983). The question of how spatial ability is defined, and its relevance to Mathematics Education. Zentralblatt fur Didaktik der Mathematik, 15, 8-20.

Education Strategic Plan (ESP) 2003-2015, Volume I. Retrieved on 25/7/2016 from http://planipolis.iiep.unesco.org/upload/Ghana/Ghana\%20Education\%20Strategic\%20Plan.pd $\underline{\mathrm{f}}$

Fennema, J. \& Sherman, J. (1977). Sex-related differences in mathematics achievement, spatial visualization and affective factors. American Educational Research Journal, Vol.14: 51-71,

Halpern, D. F. (1986) Sex Differences in Cognitive Abilities. Hillsdale, N. J. Lawrence Erlbaum Association.

McGee, M. G. (1979). Human spatial abilities: Psychometric studies and environmental, genetic,

hormonal, and neurological influences. Psychological Bulletin, 86(5), 889-918.

Mereku, D.K., (2004). Mathematics curriculum implementation in Ghana 2nd ed. Accra: Danjoe Production.

Mix, K. S., \& Cheng, Y.-L. (2012). The relation between space and math: Developmental and educational implications. In J. B. Benson (Ed.), Advances in child development and behaviour (Vol. 42, pp. 197-243). San Diego, CA: Academic Press.

Ministry of Education (2002) Meeting the Challenges of Education in the twenty first century: Report of the president's committee on review of education reforms in Ghana. Accra, Ghana.

National Council of Teachers of Mathematics (NCTM) (1989). Curriculum and evaluation standards for school mathematics. Reston, VA: NCTM

Oke, M.G. \& Bello M. A. (2014). An appraisal of candidates' achievement in the West African Senior School Certificate Examination (WASSCE) among WAEC member countries.

Sherrod, S. E., Dwyer, J. \& Narayan, R. (2009). Developing science and mathematics integrated activities for middle school students. International Journal of Mathematical Education in Science and Technology. Volume 40(2), 247-257.

Sorby, S. A. (2007). Developing 3D spatial skills for engineering students. Australasian Journal of Engineering Education, 13(1), 1-11.

Tartre, L. (1990). Spatial orientation skill and mathematical problem solving. Journal for Research in Mathematics Education, 21 (3), 216-229. USA.

Yue, J. (2002). Do basic mathematical skills improve spatial visualization abilities? Proceedings of the 2002 American Society for Engineering Education Annual Conference \& Exposition, Session 3286. 